\title{
Tekstur, Kadar $\beta$-Karoten dan Kalsium Flakes dengan Formulasi Tepung Labu Kuning dan Daun Kelor
}

\author{
Effect of formulation of pumpkin flour (cucurbita moschata) and moringa oleifera flour on \\ texture, $\beta$-carotene levels, and calcium flakes levels
}

\author{
Tiurma Wiliana Susanti Panjaitan ${ }^{1}$, Dwi Agustiyah Rosida ${ }^{2}$ \\ ${ }^{1,2}$ Fakultas Vokasi, Program Studi Agroindustri, Universitas 17 Agustus 1945 \\ Jalan Semolowaru 45 Surabaya 60119 \\ Email : tiurmawspanjaitan@yahoo.co.id
}

\begin{abstract}
Abstrak
Flakes dapat dibuat dari berbagai macam bahan makanan yang mengandung karbohidrat dan dapat ditambahkan bahan makanan sumber zat gizi lain untuk memenuhi kebutuhan gizi. Oleh karena itu, penting diciptakannya suatu produk sereal yang memenuhi kriteria sebagai pangan alternatif yang kaya akan energi, protein serta zat gizi lain seperti dan kalsium (Ca). Labu kuning mengandung $\beta$-karoten sedangkan tanaman kelor, khususnya pada daun mengandung kadar kalsium cukup tinggi. Tujuan dari penelitian ini adalah mengetahui kandungan dan Ca serta tekstur pada flakes yang disubstitusi dengan formulasi tepung labu kuning dan tepung daun kelor. Substitusi labu kuning dan daun kelor diharapkan dapat memenuhi kebutuhan akan $\beta$-karoten dan calcium. Penelitian ini merupakan penelitian eksperimental menggunakan Rancangan Acak Lengkap 1 Faktor yaitu formulasi tepung labu kuning dan tepung daun kelor untuk mensubstitusi tepung terigu, dengan komposisi F0 (100:0:0), F1 (70:27,5:2,5), F2 (70:25:5) dan F3 (70:22,5:7,5). Parameter yang diamati kadar $\beta$-karoten, kadar kalsium dan sifat fisik/tekstur dianalisis dengan analisis varian (ANAVA) dan beda nyata terkecil (BNT) bila terdapat perbedaan pada taraf nyata 5\%. Formulasi tepung labu kuning dan tepung daun kelor tidak berpengaruh terhadap tekstur flake, tetapi berpengaruh nyata terhadap kadar kalsium dan kadar betakaroten. Semakin banyak penambahan tepung daun kelor dan semakin sedikit tepung labu kuning, maka kadar kalsium semakin tinggi, sebaliknya semakin banyak penambahan tepung labu kuning dan semakin sedikit tepung daun kelor, maka kadar betacaroten semakin tinggi. Berdasarkan kandungan betakarotennya formula yang disarankan F1 karena kandungan betakarotennya paling tinggi, sedangkan dari kadar kalsium formulasi F3 karena mengandung kadar kalsium paling tinggi
\end{abstract}

Kata kunci: flake, tepung labu kuning, tepung daun kelor, $\beta$-karoten, kadar kalsium, tekstur

\begin{abstract}
Flakes can be made from various food ingredients that contain carbohydrates and can be added to other nutritional sources to meet nutritional needs. Therefore, it is important to create cereal products that meet the criteria as alternative foods rich in energy, protein and other nutrients such as calcium (Ca). Yellow squash contains $\beta$ carotene while moringa plants, especially in leaves, contain high levels of calcium. The study aims to determine the Ca content and texture of the flakes substituted with pumpkin flour and moringa leaf flour. Substitution with pumpkin and moringa leaves is expected to meet the need for $\beta$-carotene and calcium. This research is an experimental study using a completely randomized design with one factor, namely the formulation of pumpkin flour and moring leafflour to substitute wheat flour with the composition of F0 (100: 0: 0), F1 (70: 27,5: 2,5), F2 (70: 25: 5) and F3 (70:22,5: 7,5). The parameters observed were $\beta$-carotene levels, calcium levels and physical / texture properties were analyzed by analysis of variance (ANOVA) and the least significant difference (LSD) if there was a difference at the 5\% real level. The results showed that the flour formulation of pumpkin and moringa leaf had no effect on the flake texture but significantly affected calcium and $\beta$-carotene levels. The more the addition of moringa leafflour and the less pumpkin flour, the higher the calcium level. Conversely, the more pumpkin flour added, and the more moringa leaf flour reduced, the higher the $\beta$-carotene content. Based on the $\beta$-carotene content, the recommended formula is F1 because it produces the highest $\beta$-carotene content, while the F3 formulation produces the highest calcium content.
\end{abstract}

Keywords: flake, pumpkin flour, moring a leafflour, $\beta$-carotene, calcium content, texture

PENDAHULUAN

Perilaku dan kebiasan makan,

terutama dalam hal sarapan berubah mengikuti perubahan jaman. Saat ini permintaan konsumen akan sarapan beralih menjadi produk sarapan yang praktis, cepat 
saji serta bergizi, salah satunya adalah flakes (sereal). Produk flkaes merupakan produk pangan alternatif yang dapat dikonsumsi dan disukai oleh semua kalangan baik dewasa maupun anak-anak, berbentuk bulat, pipih dan tipis yang umumnya dikonsumsi dengan penambahan susu cair/susu segar sebagai menu sarapan atau sebagai cemilan (Hanawati, 2012).

Awalnya flakes dibuat dari biji jagung utuh yang dikenal dengan nama corn flakes, namun pada saat ini telah dikembangkan inovasi dalam pembuatan flakes, yaitu yang dapat dibuat dari bahan baku lain seperti umbi-umbian, kacangkacangan, dan biji-bijian guna untuk meningkatkan nilai nutrisi dan kesukaan konsumen (Hadi, dkk, 2017). Hal yang sama dikemukakan oleh Gisca, dkk (2013), selain dapat dibuat dari berbagai macam bahan makanan yang mengandung karbohidrat, flakes juga dapat ditambahkan bahan makanan sumber zat gizi lain yang bertujuan untuk memenuhi kebutuhan gizi. Zat gizi tersebut antara lain, $\beta$-karoten (senyawa provitamin A) yang berfungsi untuk penglihatan, pertumbuhan dan meningkatkan daya tahan tubuh terhadap penyakit serta kalsium (Ca). Asupan kalsium yang rendah memperlambat laju pertumbuhan dan mineralisasi tulang dan gigi. Kekurangan pada masa pertumbuhan dapat menyebabkan pengurangan massa dan kekerasan tulang yang sedang terbentuk.

Labu kuning atau waluh (Cucurbita moschata Duch.) dikenal sebagai komoditas pertanian yang mengandung $\beta$ karoten atau provitamin A, serta zat gizi yang tinggi dan baik bagi tubuh manusia, seperti protein, karbohidrat, beberapa mineral seperti kalsium, fosfor, besi; serta beberapa vitamin, yaitu vitamin $\mathrm{B}$ dan $\mathrm{C}$ (Hendrasty, 2003). Hal yang sama juga dikemukakan oleh Ripi (2011), bahwa labu kuning memiliki kandungan gizi yang cukup lengkap yakni karbohidrat, protein, dan vitamin, sehingga labu kuning dapat menjadi sumber gizi yang sangat potensial. Kandungan karbohidrat yang cukup tinggi pada labu kuning sehingga sangat berpotensi untuk diolah menjadi tepung labu kuning. Disamping kandungan gizinya cukup lengkap, labu kuning juga ketersediaannya melimpah dengan harga terjangkau, namun pemanfaatannya masih minim, padahal sangat potensial untuk dikembangkan sebagai salah satu alternatif dalam pengembangan produk labu kuning (Miyasto, 2013). Keterbatasan pengetahuan masyarakat akan manfaat komoditas pangan merupakan salah satu penyebab belum optimalnya pemanfaatan bahan pangan tersebut Widayanti dan Darmayanti, 2007)

Kandungan nilai gizi tepung labu kuning hampir sama dengan terigu dan mengandung nilai $\beta$-karoten lebih tinggi, yaitu tepung labu kuning memiliki energi $328 \mathrm{kkal}$, karbohidrat 77,6 g, protein $5 \mathrm{~g}$, lemak $0,5 \mathrm{~g}$ dan $\beta$-karoten $180 \mathrm{SI} / \mathrm{g}$, sedangkan pada tepung terigu adalah energi $365 \mathrm{kkal}$, karbohidrat 77,3 g, protein 8,9 g, lemak $1,3 \mathrm{~g}$ dan $\beta$-karoten $0 \mathrm{SI} / \mathrm{g}$, sehingga tepung labu kuning dapat menjadi alternatif untuk menggantikan tepung terigu (Gardjito, 2006 dalam Isnaini, 2016). Tepung labu kuning dapat dimanfaatkan dalam pembuatan beberapa macam produk makanan atau sebagai substitusi tepung terigu dalam berbagai pembuatan roti tawar, cake dan kue kering termasuk flakes, sehingga diharapkan dapat mendukung upaya diversifikasi makanan bagi masyarakat (Hendrasty, 2003). Tepung Labu kuning dapat digunakan sebagai alternative pengganti tepung terigu maupun tepung yang lainnya, seperti pada penelitian yang dilakukan oleh Purnamasari dan Putri (2015), melakukan penambahan tepung labu kuning dan natrium bikarbonat pada pengolahan flakes talas menunjukkankan bahwa penambahan tepung labu kuning sebanyak $10 \%$ merupakan perlakuan terbaik ditinjau dari segi organoleptic, sedangkan dari segi fisik kimia perlakuan terbaik adalah pada penambahan tepung labu kuning 30\%.

Kelor diyakini memiliki potensi untuk mengakhiri kekurangan gizi, 
kelaparan, serta mencegah dan menyembuhkan berbagai penyakit di seluruh dunia, karena kandungan kelor terbukti secara ilmiah merupakan sumber gizi berkhasiat obat yang kandungannya diluar kebiasaan kandungan tanaman pada umumnya ( Krisnadi, 2015).

Pemanfaatan daun kelor di Indonesia saat ini masih kurang dan terbatas penggunaannya (Kurniawati, dkk. 2018). Setiap bagian tanaman memiliki kandungan yang sangat penting, seperti mineral, protein, vitamin, beta-carotene, asam amino, dan berbagai phenolics. Menurut Aminah, dkk. (2015), selain dikonsumsi langsung dalam bentuk segar, kelor juga dapat diolah menjadi bentuk tepung atau powder yang dapat digunakan pada berbagai produk pangan, seperti pada olahan pudding, cake, nugget, biscuit, cracker serta olahan lainnya. Daun kelor segar dalam $100 \mathrm{~g}$ mengandung kalsium $1.077 \mathrm{mg}$, sedangkan tepung daun kelor mengandung kalsium lebih banyak yaitu 2.003,0mg. Tepung daun kelor dapat ditambahkan untuk setiap jenis makanan sebagai suplemen gizi (Prajapati, dkk, 2003). Berdasarkan hasil penelitian Majid, dkk (2017), perlakuan terbaik yang dapat diterima konsumen adalah flakes tepung terigu yang disubstitusi tepung daun kelor $5 \%$, karena daun kelor memiliki rasa pahit, bau langu dan warna gelap akibat proses pemanggangan. Kombinasi dengan tepung labu kuning yang memiliki rasa lebih enak dan warna kuning/oranye diharapkan bisa lebih diterima oleh konsumen. Disisi lain, diharapkan dapat meningkatkan kadar $\beta$ karoten dan kadar kalsium pada flakes sereal.

\section{METODE PENELITIAN}

\section{Bahan dan Alat}

Bahan-bahan yang diperlukan dalam penelitian adalah tepung labu kuning, tepung daun kelor, tepung terigu protein, air, garam, gula halus, mentega, soda kue, dan telur. Sedangkan alat yang dipergunakan adalah baskom plastik, timbangan digital, panci kukusan stainless steel, kompor, spatula, gelas ukur, oven, piring kertas, alat pengepres mie, cetakan kue, loyang dan sarung tangan

\section{Metode Penelitian}

Penelitian ini merupakan penelitian eksperimental dengan menggunakan Rancangan Acak Lengkap 1 Faktor yaitu formulasi tepung labu kuning dan tepung daun kelor untuk mensubstitusi tepung terigu dengan komposisi: F0 (100:0:0), F1 $(70: 27,5: 2,5), \quad$ F2 $\quad(70: 25: 5)$ dan F3 $(70: 22,5: 7,5)$.

\section{Pembuatan Flakes}

Pelaksanaan pembuatan flakes pada penelitian ini dilakukan dengan cara menimbang semua bahan sesuai dengan komposisi perlakuan. Tepung terigu, tepung labu kuning dan tepung daun kelor ditempatkan dalam wadah yang kering dan bersih sesuai perlakuan, kemudian tambahkan garam, gula halus, soda kue, margarine, telur. Semua bahan dicampur rata dan ditambahkan air hingga tercampur dan menjadi adonan. Kemudian adonan dikukus (steam blancing) selama 10 menit, selanjutnya digiling dalam cetakan mie hingga tipis dan ketebalannya sama 1,5-2 $\mathrm{mm}$ (skala 3 pada alat penggiling mie). Bahan yang sudah digiling dicetak/dibentuk, kemudian dipanggang pada oven $140^{\circ} \mathrm{C}$ selama 45 menit. Variabel flakes yang diamati adalah tekstur, kadar kalsium dan kadar betakaroten. Pengujian tekstur dilakukan dengan menggunakan penetrometer, yaitu alat yang digunakan untuk mengukur tingkat kekerasan atau tekstur suatu bahan dengan prinsip mengukur kedalaman masuknya jarum penusuk. Kadar kalsium diuji menggunakan metode Atomic Absorbance Spektrofotometri (AAS), yaitu berdasarkan absorpsi radiasi sinar ultraviolet atau sinar tampak oleh atom-atom bebas pada tingkatan gas. Prosedur dilakukan dengan pembuatan larutan standar $\mathrm{Ca}^{2+}$ dilanjutkan preparasi sampel dengan pengabuan basah, kemudian persiapan alat dan pengukuran absorbansi dengan AAS. Sedangkan kadar 
betakaroten diuji menggunakan High Performance Liquid Cromatography (HPLC) Agilent 110 Series dengan autosampler dan DAD.

\section{Analisis dan Interpretasi Data}

Semua data yang dikumpulkan, yaitu kadar $\beta$-karoten, kadar kalsium dan sifat fisik/tekstur dianalisis menggunakan analisis variansi (ANAVA), jika terdapat perbedaan dilanjutkan dengan uji beda nyata terkecil (BNT pada taraf nyata 5\%.

\section{HASIL DAN PEMBAHASAN Tekstur}

Hasil nilai rata-rata tekstur pada tabel 1. menunjukkan bahwa formulasi tepung labu kuning dan tepung daun kelor tidak berpengaruh nyata terhadap tekstur pada taraf nyata 5\%, sehingga penelusuran lebillhabel lanjut dengan uji BNT tidak dilakukan karena semua perlakuan tidak menunjukkan adanya perbedaan tekstur.

Tabel 1. Nilai Rata-Rata Tekstur Flakes

\begin{tabular}{|c|c|}
\hline Perlakuan & $\begin{array}{c}\text { Tekstur/Hardness } \\
(\mathrm{mm} / 100 \mathrm{~g} / 10 \mathrm{det})\end{array}$ \\
\hline F0 & $1.9333 \pm 0.1155^{\mathrm{a}}$ \\
\hline F1 & $2.2667 \pm 0.4619^{\mathrm{a}}$ \\
\hline F2 & $1.6667 \pm 0.6110^{\mathrm{a}}$ \\
\hline F3 & $1.6667 \pm 0.4163^{\mathrm{a}}$ \\
\hline
\end{tabular}

Tekstur pada makanan adalah hal yang berkaitan dengan struktur makanan yang dirasakan di mulut. Proses pembentukan tekstur dipengaruhi oleh adanya molekul karbohidrat, serat dan protein dengan membutuhkan air. Terigu memiliki gluten yang merupakan protein lengket dan elastis yang terkandung di dalam beberapa jenis serealia, terutama gandum yang merupakan bahan utama dalam pembuatan terigu yang berpengaruh besar pada kemampuan terbentuknya lapisan yang mengembang membentuk lapisan rongga. Selain itu, pembentukan kerangka adonan dapat terjadi dengan kemampuan gelatinisasi karbohidrat ketika adonan dipanggang. Menurut Williams dan Margareth (2001) dalam Wahyudin (2018), karbohidrat merupakan komponen lain yang penting pada tepung terigu dan tepung lainnya akan mengikat air serta terjadi gelatinisasi dan akan hilang pada saat pemanggangan yang menyebabkan adonan berubah menjadi renyah pada produk panggang. Dengan demikian peranan karbohidrat yang terdapat pada terigu dapat digantikan dengan tepung lainnya yang memiliki kadar relatif sama (Richana, 2010 dalam Wahyudin, 2018). Kandungan nilai gizi, seperti karbohidrat pada tepung labu kuning sebesar 77,6g hampir sama dan tepung terigu, yaitu 77,3 g (Gardjito, 2006 dalam Isnaini, 2016).

\section{Kadar Kalsium}

Hasil analisis kadar kalsium flakes dapat di lihat pada Tabel 2

2. Nilai Rata-Rata Kadar Kalsium Flakes

\begin{tabular}{|c|c|}
\hline Perlakuan & $\begin{array}{c}\text { Kadar Kalsium } \\
(\mathrm{mg} / 100 \mathrm{gr})\end{array}$ \\
\hline F0 & $132.9967 \pm 6.7644^{\mathrm{a}}$ \\
\hline F1 & $136.5900 \pm 5.7526^{\mathrm{a}}$ \\
\hline F2 & $166.5933 \pm 7.2616^{\mathrm{b}}$ \\
\hline F3 & $267.9575 \pm 6.6776^{\mathrm{c}}$ \\
\hline $\begin{array}{l}\text { Keterangan: Nilai rata-rata yang } \\
\text { didampingi } \\
\text { menyatakan terdapat perbedaan yang nyata }\end{array}$
\end{tabular}

Hasil rata-rata nilai kadar kalsium menunjukkan bahwa semua formulasi penambahan tepung labu kuning dan tepung daun kelor menunjukkan adanya perbedaan yang signifikan, kecuali antara F0 (tanpa peanambahan tepung labu kuning dan daun kelor) dengan F1 (penambahan tepung labu kuning $27.5 \%$ dan daun kelor $2.5 \%$ ) tidak menunjukkan perbedaan yang signifikan. Kadar kalsium terendah dijumpai pada F0 (132,9967mg/100g), sedangkan kadar kalsium tertinggi dijumpai pada F3 (penambahan tepung labu kuning $22.5 \%$ dan tepung daun kelor $7.5 \%$ ) dengan kadar 267,9575 mg/100g Hal ini menunjukkan bahwa semakin banyak penambahan tepung daun kelor dan semakin sedikit tepung labu kuning, maka kadar kalsium semakin tinggi. Hal ini 
disebabkan karena tepung daun kelor memiliki kandungan senyawa mineral yang cukup tinggi, antara lain kalsium yaitu sebesar 2003 mg/100g (Bey, 2010). Hasil analisis karakteristik tepung daun kelor yang dilakukan oleh Kurniawati, dkk, (2018) menyebutkan bahwa tepung daun kelor mengandung kalsium sebesar 16.350,58 ppm, sedangkan labu kuning mengandung kalsium dengan kadar yang lebih rendah yaitu $45 \mathrm{mg} / 100 \mathrm{~g}$ bahan (Hendrasty, 2003).

\section{Kadar Beta Karoten}

Hasil analisis kadar beta karoten flakes dapat dilihat pada Tabel 3.

Tabel 3. Nilai Rata-Rata Kadar Betakaroten Flakes

\begin{tabular}{|c|c|}
\hline Perlakuan & $\begin{array}{c}\text { Kadar Beta Karoten } \\
(\% \mathrm{~b} / \mathrm{b})\end{array}$ \\
\hline F0 & Tidak terdeteksi $^{\mathrm{a}}$ \\
\hline F1 & $.21400 \pm .004359^{\mathrm{b}}$ \\
\hline F2 & $.20100 \pm .002000^{\mathrm{c}}$ \\
\hline F3 & $.19300 \pm .002646^{\mathrm{d}}$ \\
\hline
\end{tabular}

Keterangan: Nilai rata-rata yang didampingi huruf yang berbeda menyatakan terdapat perbedaan yang nyata

Hasil rata-rata nilai kadar betakaroten menunjukkan bahwa semua formulasi penambahan tepung labu kuning dan tepung daun kelor menunjukkan adanya perbedaan yang signifikan. Kadar beta karoten terendah dijumpai pada F3 (penambahan tepung labu kuning 22.5\% dan tepung daun kelor $7.5 \%$ ) dengan kadar 0,193\%, sedangkan kadar kalsium tertinggi dijumpai pada F1 (penambahan tepung labu kuning $27.5 \%$ dan tepung daun kelor 2.5\%) dengan kadar 0,214\%. Hal ini menunjukkan bahwa semakin banyak penambahan tepung labu kuning dan semakin sedikit tepung daun kelor, maka kadar betacaroten semakin tinggi.

Kadar betakaroten pada suatu produk pangan sangat penting, karena betakaroten ini ketika didalam tubuh akan berfungsi sebagai pro vitamin A. Labu kuning dikenal sebagai salah satu produk nabati yang mengandung kadar betakaroten cukup tinggi (Hendrasty, 2003), warna kuning yang terdapat pada daging labu kuning dapat mengindikasikan adanya pigmen betakaroten. Menurut Krisnadi (2015), daun kelor juga mengandung betakaroten yang berfungsi sebagi provitamin A. Peningkatan kandungan betakaroten seiring dengan semakin meningkatnya penambahan tepung labu kuning dalam formula ini disebabkan karena senyawa karoten, terutama betakaroten yang terkandung dalam labu kuning lebih tinggi dibandingkan tepung daun kelor yang juga mengandung senyawa betakaroten dengan kandungan betakaroten lebih rendah. Hal ini didukung dari hasil analisis kandungan betakaroten terhadap bahan baku flakes yang digunakan pada penelitian ini, yaitu tepung labu kuning mengandung betakaroten sebesar $2,1761 \mathrm{mg} / 100 \mathrm{mg}$ $(2,1761 \% \mathrm{~b} / \mathrm{b})$ dan tepung daun kelor mengandung $1,4679 \mathrm{mg} / 100 \mathrm{mg}(1,4679 \%$ $\mathrm{b} / \mathrm{b})$ betakaroten.

\section{SIMPULAN DAN SARAN}

Formulasi tepung labu kuning dan tepung daun kelor tidak berpengaruh terhadap tekstur flake, tetapi berpengaruh nyata terhadap kadar kalsium dan kadar beta karoten. Semakin banyak penambahan tepung daun kelor dan semakin sedikit tepung labu kuning, maka kadar kalsium semakin tinggi, sebaliknya semakin banyak penambahan tepung labu kuning dan semakin sedikit tepung daun kelor, maka kadar betacaroten semakin tinggi.

Berdasarkan hasil penelitian formula yang disarankan ditinjau dari kandungan betakarotennya adalah F1 karena kandungan betakarotennya paling tinggi sedangkan dari kadar kalsium yang disarankan adalah formulasi F3 karena mengandung kadar kalsium paling tinggi.

\section{UCAPAN TERIMA KASIH}

Terima kasih kepada Bapak Rektor Universitas 17 Agustus 1945 melalui LPPM Untag Surabaya yang telah membiayai kegiatan penelitian Hibah Perguruan Tinggi tahun anggaran 2020. 
Penulis juga menyampaikan terima kasih kepada Kepala Laboratorium Pangan Untag Surabaya.

\section{DAFTAR PUSTAKA}

Aminah, S., Ramdhan,T dan Yanis,M. 2015. Kandungan Nutrisi dan Sifat Fungsional Tanaman Kelor ( $M$ oringa oleifera). Buletin Pertanian Perkotaan Volume 5 Nomor 2.

Bey, Hakim. 2010. All Things Moringa. www.allthingsmoringa.com

Gisca I.D, Bernadheta., dan Arintina Rahayuni., 2013. Penambahan Gembili Pada Flakes Jewawut Ikan Gabus Sebagai Alternatif Makanan

Tambahan Anak Gizi Kurang. Program Studi Ilmu Gizi. Fakultas Kedokteran. Universitas Diponegoro. Semarang.

Hadi, N., Yusmarini dan Efendi, R. 2017. Pemanfaatan Tepung Biji Nangka Dan Tepung Jagung Dalam Pembuatan Flakes. Jom FAPERTA Vol. 4 No. 2.

Hanawati, R.F. 2012. Proses Produksi Flakes Kaya Antioksidan sebagai Alternatif Diversifikasi Ubi Jalar Ungu [Skripsi]. Surakarta: Fakultas Pertanian. Universitas Sebelas Maret.

Hendrasty, Henny Krissetiana. 2003. Tepung Labu Kuning (Pembuatan dan Pemanfaatannya). Penerbit Kanisius. Yogyakarta.

Isanini, Aan Nur. 2016. Pengaruh Substitusi Tepung Labu Kuning (Cucurbita Moschata) Dalam Pembuatan Pancake Terhadap Kadar Beta Karoten Dan Daya Terima. Skripsi. Universitas Muhammadiyah Surakarta.

Krisnadi, A. Dudi. 2015. Kelor Super Nutrisi. Pusat Informasi Dan Pengembangan Tanaman Kelor Indonesia. Lembaga Swadaya Masyarakat - Media Peduli Lingkungan (LSM-MEPELING). Kelorina.com
Kurniawati, I., Fitriyya, M dan Wijayanti. 2018. Karakteristik Tepung Daun Kelor Dengan Metode Pengeringan Sinar Matahari. Prosiding Seminar Nasional Unimus, Vol 1. Majid, F.R., Hidayat,N dan Waluyo. 2017. Variasi Penambahan Tepung Daun.

Prajapati RD, Murdia PC, Yadav CM, Chaudhary JL. 2003. Nutritive value of Teknologi Hasil Pertanian, Universitas Sebelas Maret Surakarta

Purnamasari, I.W dan Putri, W.D.R. 2015. Pengaruh Penambahan Tepung Labu Kuning Dan Natrium Bikarbonat Terhadap Karakteristik Flake Talas. Jurnal Pangan dan Agroindustri Vol. 3 No 4 p.1375-1385.

Rakhmawati, N. 2013. Formulasi dan Evaluasi Sifat Sensoris dan Fisikokimia Produk Flakes Komposit Berbahan Dasar Tepung Tapioka, Tepung Kacang Merah (Phaseolus vulgaris L.) dan Tepung Konjac (Amorphophallus oncophillus). Skripsi. Jurusan Teknologi Hasil Pertanian, Universitas Sebelas Maret Surakarta.

Ripi, V.I. 2011. Pembuatan Dan Analisis Kandungan Gizi Tepung Labu Kuning (Cucurbita Moschata Duch. Skripsi. Teknik Kimia UPN "Veteran" Jawa Timur.

Tahir, M., Hikmah, N., dan Rahmawati. 2016. Analisis Kandungan Vitamin C dan $\beta$-Karoten Dalam Daun Kelor (Moringa oleifera Lam.) Dengan Metode Spektrofotometri UV-VIS. Jurnal Fitofarmaka Indonesia, Vol. 3 No. 1.

Widayati, E dan Damayanti, W. 2007. Aneka Pengolahan dari Labu Kuning. Jakarta: Trubus Agrisarana 